Original Research Paper

\title{
GIS Mapping of Basal Stem Rot Disease in Relation to Soil Series Among Oil Palm Smallholders
}

\author{
${ }^{1}$ Parthiban, K., ${ }^{2}$ R. Vanitah, ${ }^{3}$ K. Jusoff, ${ }^{4}$ A.A. Nordiana, ${ }^{5}$ A.R. Anuar, ${ }^{6}$ O. Wahid and ${ }^{7}$ A.B. Hamdan \\ ${ }^{1,7}$ Extension Services Unit, Integration Research and Extension Division, \\ Malaysian Palm Oil Board, No 6, Persiaran Bandar Baru Bangi, 43000 Kajang, Selangor, Malaysia \\ ${ }^{2}$ Faculty of Science and Technology, Universiti Kebangsaan Malaysia, 43600 Bangi, Selangor, Malaysia \\ ${ }^{3}$ Information Technology and Corporate Services Division, Malaysian Palm Oil Board, No 6, \\ Persiaran Bandar Baru Bangi, 43000 Kajang, Selangor, Malaysia \\ ${ }^{4}$ Agronomy and Geospatial Technology Unit, Biological Research Division, \\ Malaysian Palm Oil Board, No 6, Persiaran Bandar Baru Bangi, 43000 Kajang, Selangor, Malaysia \\ ${ }^{5}$ Department of Soil Science, Faculty of Agriculture, \\ Universiti Putra Malaysia, 43400 Serdang, Selangor, Malaysia \\ ${ }^{6}$ Integration Research and Extension Division, \\ Malaysian Palm Oil Board, No 6, Persiaran Bandar Baru Bangi, 43000 Kajang, Selangor, Malaysia
}

Article history

Received: 19-03-2015

Revised: $16-12-2015$

Accepted: 04-01-2016

Corresponding Author: Parthiban, K.

Extension Services Unit, Integration Research and Extension Division, Malaysian Palm Oil Board, No 6, Persiaran Bandar Baru Bangi, 43000 Kajang, Selangor, Malaysia

Tel: +60389261854

Email: parthiban@mpob.gov.my

\begin{abstract}
Basal Stem Rot (BSR) is a disease caused by fungus which affect oil palm tree. This study aims to visualize the geographical distribution of BSR incidence among oil palm smallholders in Selangor using Geographical Information System (GIS) and its relationship to the type of soil series. The geographical distribution of BSR incidence of smallholders in Selangor were mapped using 168 Global Positioning System (GPS) coordinate of possible infected area. The methodology followed in finding the relationship between BSR and soil series by assigning percentage of BSR incidence based on type of soil series. Majority of the BSR incidences were found to be confined to the Selangor-Kangkong (Aeric Tropic Fluvaquent-Typic sulfuric tropic fluvaquent) soil series followed on Peat (Typic Fibric Tropohemist) soil then Kranji (Typic Sulfaquents) soil series and finally the Briah-Organic Clay and Muck (Typic Tropic Fluvaquent) soil series. Distribution pattern of the BSR revealed that most of the incidences were confined along the coastal area which might be due to the planting of oil palm in previous coconut stands. Low $\mathrm{pH}$ of Selangor (Aeric Tropic Fluvaquent) and Peat (Typic Fibric Tropohemist) soil series shows a higher BSR incidence while high $\mathrm{pH}$ of Kranji (Typic Sulfaquents) and Briah (Typic Tropic Fluvaquent) soil series shows slightly lower BSR incidence. From this study, it can be concluded that the distribution of BSR were mostly confined to the coastal areas which might be due to the planting of oil palm in previous coconut stands rather than any relationship with the type of soil series. This distribution map of BSR incidence can be used to deliver effective extension services regarding BSR to smallholders with a specified target based on location and soil series.
\end{abstract}

Keywords: GIS Mapping, Basal Stem Rot Disease, Soil, Oil Palm

\section{Introduction}

Oil palm was considered as one of the world's valuable oil crops with the highest yield per hectare production compare to other oil crops. The high yields of oil palm have led to a rapid expansion of oil palm production especially in the tropical areas of Asia such as Malaysia and Indonesia. Currently, there are 5.22 million hectares of oil palm in Malaysia which include all the big plantations (MPOB, 2013). While the big plantation companies has a strong presence, the smallholders plays a significant part in the oil palm industry as there about 685,286 ha of oil palm land that are belongs to independent smallholders, accounting for $14 \%$ of the country's total oil palm-planted area of 5.22 million ha (MPOB, 2013). According to Malaysian Palm 
Oil Board (MPOB), independent oil palm smallholders in Malaysia are those who own oil palm land of below 40.48 hectare or 100 acre while oil palm lands more than 100 acre were classified as estate.

These huge areas under oil palm are under threat by Basal Stem Rot (BSR) disease which were generally associated with fungus from Ganoderma species. Three species of Ganoderma which are found to be pathogenic to oil palm are G.boninense, $G$. zonatum and $G$. miniatocinctum while $G$. tornatum are not pathogenic (Idris et al., 2000a; 2000b). Financial losses begin to happen when the disease affects more than ten percent of the oil palm stand. Infected mature palms might take up to 2-3 years to die after the first appearance of symptoms but young oil palm normally will die within 6 to 24 months (Cooper et al., 2011). Previously at the early stage, the disease was reported to infect mostly palms of more than 30 years old. In 1957, the diseases were reported to appear on 10-15 years old trees followed by in much younger palms of 1-2 years since the year 1990 (Wong et al., 2012; Azahar et al., 2011). BSR infected palm shows several sign of external symptoms such as the decay of the palm bole, multiple unopened spear leaves, production of fruiting bodies on the trunk base. In severe cases, the palm usually dies or falls over. Continuous new planting of oil palm in the same areas and planting in field which formerly was planted with coconut happen to contribute to the spreading of the disease to younger palms. Fresh Fruit Bunch (FFB) of oil palm production which adversely affected by the disease incidence not only occurs through yield loss from dead oil palm tree but also through yield reduction from living diseased palm through reduction in terms of weight and number of fruit bunch. In 2009, the estimated areas that were affected by Ganoderma in Malaysia are about 151,208 hectares with an estimated loss of RM1.3 billion. It has been estimated that a total of 400,000 ha could be affected by Ganoderma disease in Malaysia by 2020 (Arif et al., 2011; Roslan et al., 2012).

There are limited studies on the distribution of BSR incidence among smallholders in Malaysia. Most of the studies were based on big plantation company which emphasize on their specific land area. Advancement in technology have resulted in the introduction of Geographical Information System (GIS) and Global Positioning System (GPS) which can be used to map the distribution of disease over a large area of land. The objectives of this study are two-folds, namely to map the distribution of Basal Stem Rot disease among oil palm smallholders in Selangor using GIS and to determine if there is any relationship between Basal Stem Rot distribution and type of soil series.

Knowledge on the findings will help to deliver effective extension services on BSR management to smallholders with a specified target based on location and soil series. The distribution map of BSR incidence from this study can be used for future planning of program such as replanting or new planting of oil palm in Selangor. Other than that, the distribution map of BSR incidence in Selangor can be used to deliver effective extension services on BSR to smallholders with a specified target based on location and soil series as well as, to promote early management practices of BSR disease to other nearby land within the affected area.

\section{Literature Review}

Many reports stated that environmental condition such as soil type and soil properties might affect the development of plant disease caused by fungus. For example, it has been reported that the stability of suppressiveness to Fusarium wilt were attributed to soil type and soil properties. The nature of clays and $\mathrm{pH}$ plays a significant factor in soils suppressive to Fusarium wilts (Alabouvette, 1999). A close link was reported between suppression of Fusarium wilt and the presence of clay soils in tropical America whereby in the Canary Islands, suppression of disease was related with host mineral nutrition (Ploetz, 2000). The same scenario as above on the effect of soil type and properties on plant disease development might be applied to Ganoderma disease of oil palm which also caused by fungus.

Under laboratory conditions, Ganoderma boninense are found to grow at an optimum $\mathrm{pH}$ of between 3.7 to 5.0 and optimum temperature between $27-30^{\circ} \mathrm{C}$ (Nawawi and Ho, 1990). At the field condition, this may represent huge range of oil palm growing condition and soil types. The influence of soil type on disease occurrence were not yet fully understood or reported. High soil moisture condition of coastal soils might have benefited Ganoderma to grow without much competition over other, antagonistic soil fungi (Gurmit, 1991). Clay soils with poor drainage and a high water retention capacity might favour BSR disease. However, this report were contradict with recent report by Chang (2003) which suggested to flood the infected area as a way to control the fungi based on the inability of Ganoderma boninense to survive in a condition of high soil moisture which were tested based on laboratory condition. Gurmit (1991) reported that low soil $\mathrm{pH}$ and high salinity appeared to suppress the disease in which BSR incidence was found to be lower on acid sulphate (Sedu series) soils and on recent marine soils as reported in Table 1.

BSR disease once has been considered to infect mostly in coastal marine clay areas of western Peninsular Malaysia such as Kangkong, Selangor, Briah, Bernam, Carey, Sedu, Sogomana, Tangkang, Parit Botak, Jawa, Sabrang, Merbok and Linau (Navaratnam, 1964). This is due to planting of oil palm on former coconut areas (Turner, 1981) and the nature of the water table and soil in which this soil are mainly clays, clay loams or silty clays with high water retention capacity and poor internal drainage (Turner, 1981; Gurmit, 1991; Khairudin, 1990). 
Table 1. Effect of soil acidity and soil salinity on Basal Stem Rot incidence in oil palm (Gurmit, 1991)

\section{Replant from oil palms}

Soil series

Sedu series (acid sulphate)

Akob/Merbau patah (non-acid sulphate)

Replant from coconut

Conductivity in top $30 \mathrm{~cm}$ soil $(\mu \mathrm{s} / \mathrm{cm})$

500

1000

In recent years, BSR disease has also been reported in inland areas such as Holyrood, Sungei Buloh, Rasau, Bungor, Batu Anam/Durian and Munchong series and it also found to occur on oil palms growing in lateritic soils such as Malacca series which were previously thought to be disease free (Gurmit, 1991; Khairudin, 1990; Rao et al., 2003). BSR also has been detected in peat soils which previously were thought to be non-conducive to BSR disease suggesting that this disease poses a threat across different type of soil. Increasing reports of BSR disease in different soil types requires further investigation to determine if there is any specific relationship between factors such as soil types, temperature, rainfall pattern and fertilizer application in aggravating the disease. The disease also has been reported to normally occur in the valleys compare on the hill slopes (Gurmit, 1991).

The nutritional status of a plant or soil has a major impact on disease susceptibility and this has been exploited for suppressing a variety of diseases. The nutrient availability of soils may influence the development of the disease by affecting the enzyme production by the fungus. It also may be due to better formation of cell wall of plant due to nutrient present such as calcium. Some research reported that combination of calcium, copper and salicylic acid has suppressed the development of BSR (Rahamah et al., 2012; Sariah and Zakaria, 2000). Gurmit (1991) reported that fertilizer trials conducted on the Briah-Selangor series showed that muriate of potash $(\mathrm{KCI})$ and rock phosphate had an increase effect on disease occurrence while urea had a reduced effect. Another report on marine alluvium of the Bernam series shows it significantly reduce disease incidence with muriate of potash while urea and rock phosphate had a slight increase effect. Ganoderma is found to produce lignin degrading enzyme which would degrade lignin of oil palm to obtain energy from cellulose (Paterson et al., 2008). There is possibility to control Ganoderma infection in oil palm by altering lignin content of oil palm (Paterson et al., 2009). Calcium is well known as a macronutrient which can help in strengthening the cell wall as well as membrane permeability of plant tissues which can be used to enhance resistance towards Ganoderma.

Palm trees planted with higher density were reported to contribute to higher BSR incidence
BSR incidence at 12 years $(\%)$

1.9

23.4

BSR incidence at 15 years $(\%)$ 44.6

8.4 compared to palm trees planted in lower density (Azahar et al., 2011). Studies on patterns of the BSR disease in oil palms reported that diseased palms tend to be in clumps in some fields, which suggests that the spread of disease might be through root contact. Root contact has been reported to be the main mode of infection of BSR (Rees et al., 2009). Efforts are also being done to identify genetic factors that responsible for pathogenicity of Ganoderma with a recent study conducted by Omar et al. (2014) to isolate and characterize these genes. Apart from that, certain soil fungi are found to be capable of forming symbiotic relationship with plant which may help to inhibit plant diseases. Few selected endophytic Trichoderma have been reported to have the capability to inhibit G.boninense growth (Shamala, 2013).

\section{Materials and Methods}

\section{Study Area}

The study area of Selangor state were located on the west coast of Peninsular Malaysia between latitudes $2^{\circ} 39^{\prime} 18.0^{\prime \prime} \mathrm{N}$ and $3^{\circ} 50^{\prime} 54.4^{\prime \prime} \mathrm{N}$ and longitudes $101^{\circ} 44^{\prime} 49.0^{\prime \prime} \mathrm{E}$ and $100^{\circ} 52^{\prime} 07.7^{\prime \prime E}$ (Fig. 1). It covers an area of about 8000 square kilometer. It was bounded in the north by the Bernam river, in the south by the Sepang river and in the west by Malacca straits. The mean annual temperature is $26^{\circ} \mathrm{C}$ with average daily temperature ranges from 21 to $32^{\circ} \mathrm{C}$. It receives annual rain fall of $1200 \mathrm{~mm}$ (Olaniyi et al., 2012). Selangor state consists primarily of coastal plain of alluvial soils bordering the Straits of Malacca.

There are five major rivers in Selangor. The Bernam and Selangor River drain the northern part of Selangor and Klang river drain the centre while Langat and Sepang rivers drain the northern part. These rivers overflow their banks after heavy rains thus leaving a fine riverine alluvium. The alluvium comprises of coastal and inland deposits. The coastal alluviums which were confined to the coastal area consists mainly of clay and silt. Inland alluvium on the other hand were mainly confined to the flood plains of the rivers and streams.

The most extensive soils on the coastal plain of Selangor are the Selangor series (Table 2). It has composition of $65 \%$ clay, $25 \%$ silt, $4 \%$ fine sand and $1 \%$ coarse sand at a depth of $0-22.5 \mathrm{~cm}$ (Wong, 1970). 
Table 2. Soil type in Selangor state (adapted from Wong, 1970)

\begin{tabular}{|c|c|c|}
\hline Soil type (Local name) & USDA Soil Taxanomy & Acre \\
\hline Rengam series & Typic Paleudult & 89,573 \\
\hline Serdang-Munchong association & Typic Paleudult(Serdang) \& Typic Hapludox (Munchong) & 78,875 \\
\hline Serdang-Munchong-Kedah association & Typic Paleudult (Serdang) \& Typic Hapludox(Munchong) \& Lithic Hapludult(Kedah) & 67,213 \\
\hline Serdang-Munchong-Seremban association & Typic Paleudult(Serdang) \& Typic Hapludox(Munchong) \& Plinthic paleudult (seremban) & 59,885 \\
\hline Serdang-Kedah-Durian association & Typic Paleudult (Serdang) \& Lithic Hapludult (Kedah) \& Plinthaquic Paleudult (Durian) & 23,482 \\
\hline Kedah-Serdang-Munchong association & Lithic Hapludult (Kedah) \& Typic Paleudult (Serdang) \& Typic Hapludox (Munchong) & 12,570 \\
\hline Kedah-Batu Anam-Durian association & Lithic Hapludult (Kedah) \& Aquic Paleudult (Batu Anam) \& Plinthaquic Paleudult (Durian) & 62,221 \\
\hline Munchong-Seremban association & Typic Hapludox (Munchong) \&Plinthic paleudult (seremban) & 18,913 \\
\hline Tavy-Bungor association & Typic Paleudult (Bungor) & 1,497 \\
\hline Malacca series & Xanthic Hapludox & 2,335 \\
\hline Prang series & Typic Hapludox & 3,738 \\
\hline Selangor-Kangkong association & Aeric Tropic Fluvaquent (Selangor) \&Typic sulfuric tropic fluvaquent & 62,000 \\
\hline Selangor-Briah association & Aeric Tropic Fluvaquent (Selangor) \& Typic Tropic Fluvaquent (Briah) & 245,384 \\
\hline Briah series & Typic Tropic Fluvaquent & 27,000 \\
\hline Selangor-telokassociation & Aeric Tropic Fluvaquent (Selangor) & 39,320 \\
\hline Merbau patah-Akob association & Typic Endoaquepts (Merbau)-Aeric Tropaquepts (Akob) & 4,843 \\
\hline Jambu series & Spodic Quartzipsamment & 883 \\
\hline Kranji series & Typic Sulfaquents (Kranji) & 83,902 \\
\hline Kranji-Mangrove Swamp association & Typic Sulfaquents (Kranji) - Mangrove swamp & 40,698 \\
\hline Inland Swamp association & - & 542,200 \\
\hline Local alluvium-colluvium association & - & 48,214 \\
\hline Steepland & Miscellaneous soils & 410,382 \\
\hline Disturbed land & Urban and mining land & 95,752 \\
\hline
\end{tabular}

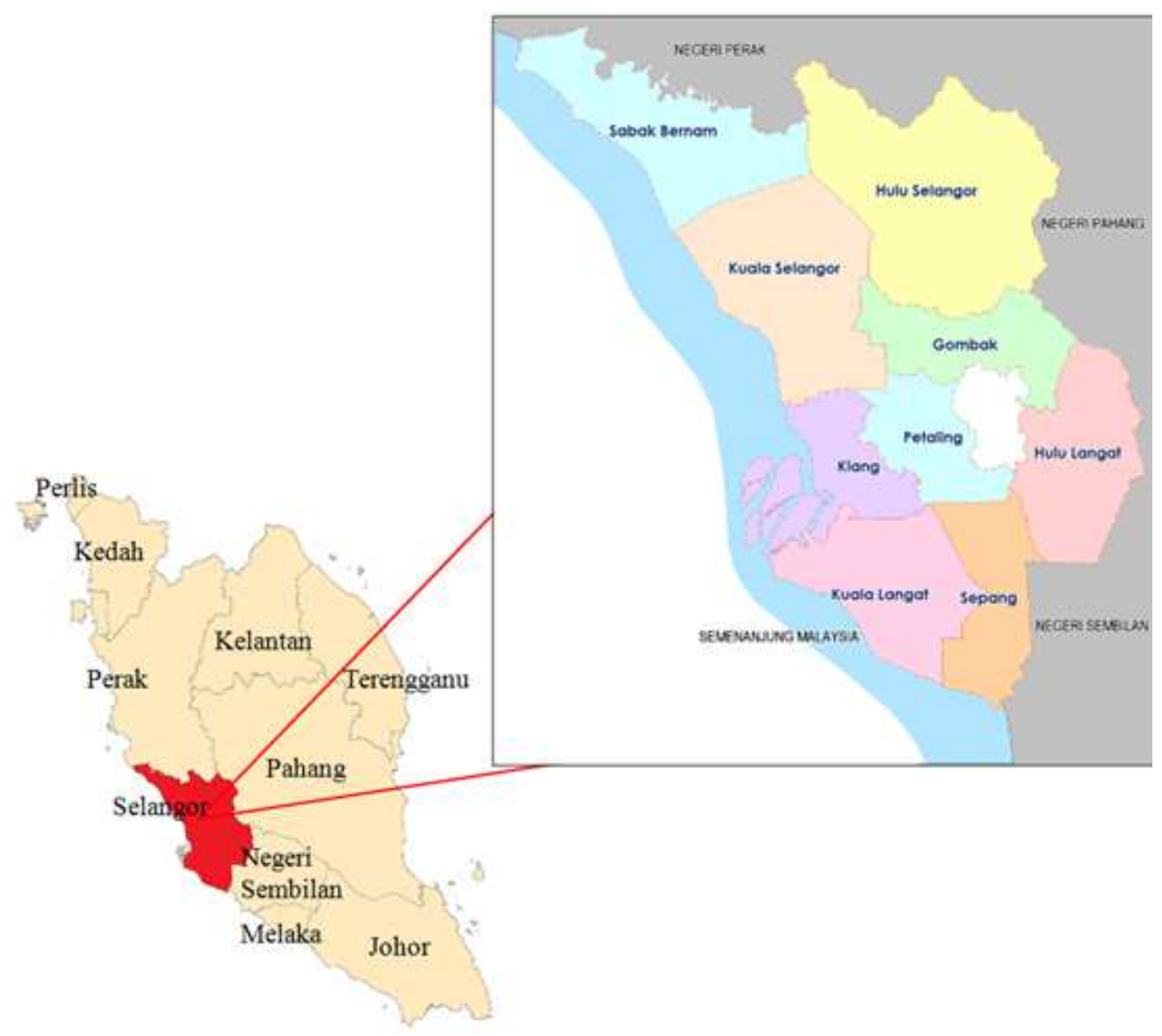

Fig. 1. Location map of the study area of Selangor state (Source: Economic Planning Unit of Selangor, 2014) 
GPS data collection of ganoderma incidence

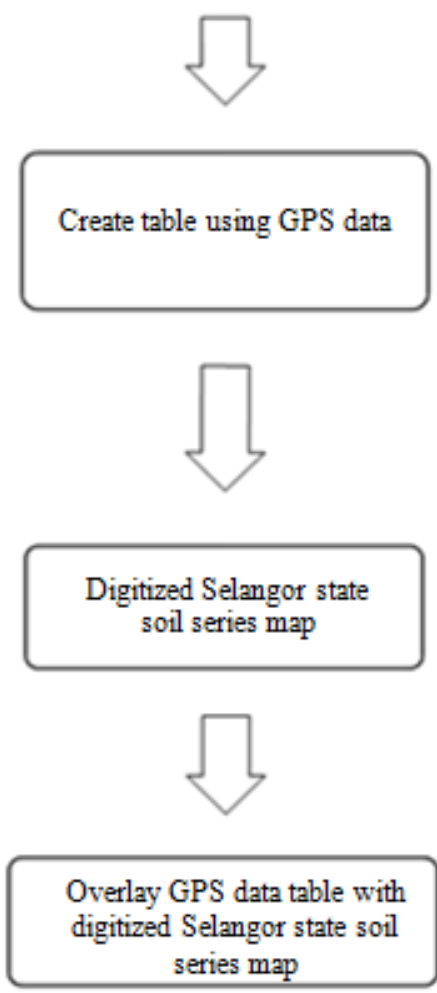

Fig. 2. Diagrammatic flowchart of the research methodology

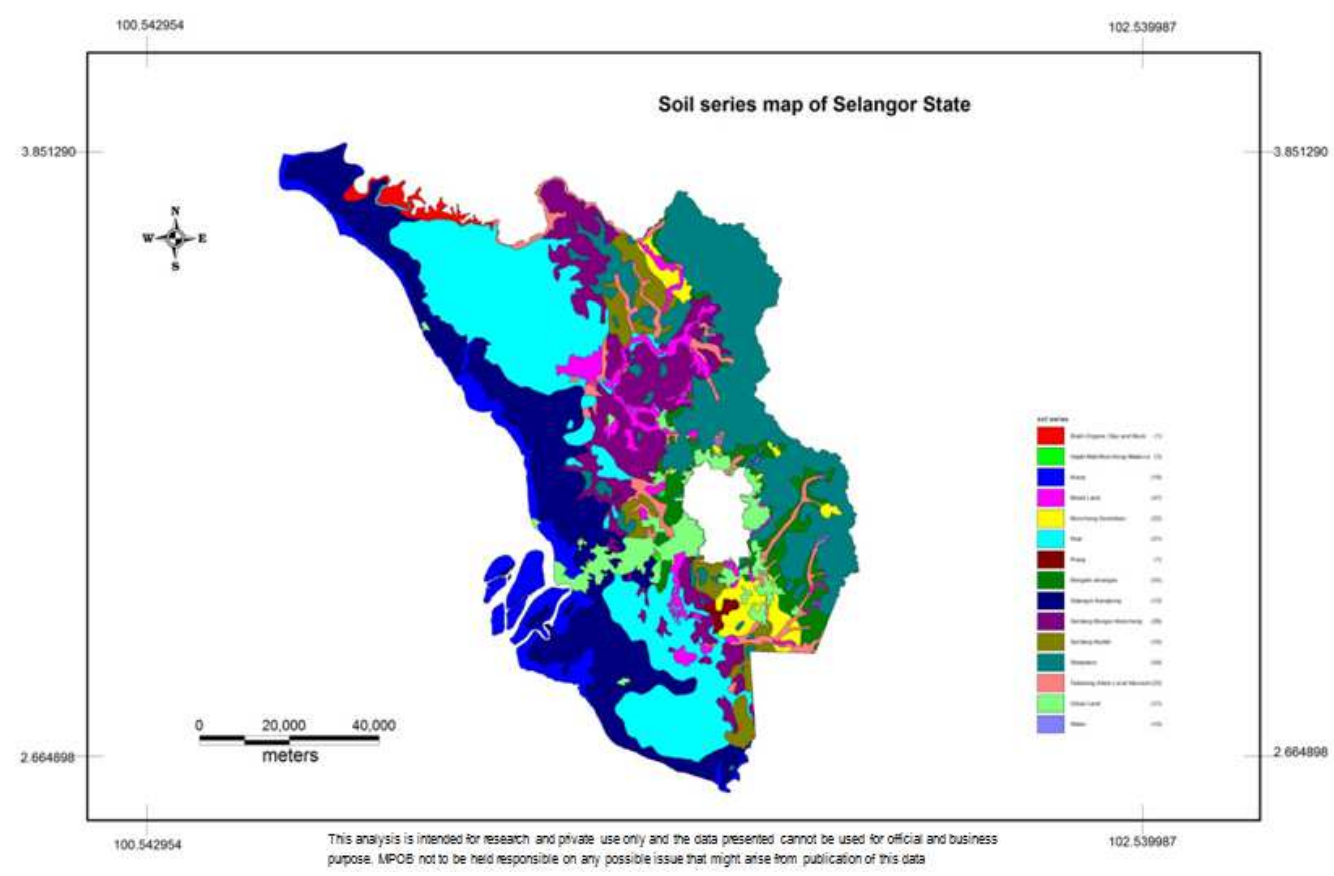

Fig. 3. Soil series map of Selangor state 
It is in class I soil which is ideally suited for the cultivation of oil palm. When this soil were imperfectly drained it would be a class II soil and converted into class III under irrigated condition.

Another extensive soil in Selangor is the Serdang Series. It is developed on quartzites, sandstones and sandy shale. It has composition of $28 \%$ clay, $4 \%$ silt, $45 \%$ fine sand and $25 \%$ coarse sand at a depth of $0-6 \mathrm{~cm}$ (Wong, 1970). Soils of the Serdang series have been places in class I and II because of the slope of below $6^{\circ}$ and thickness of the profile which enhances drainage, aeration and root penetrability.

Selangor as a total have about 164,708 hectare of peat land in which 46,456 hectare were under oil palm cultivation (Wetlands International, 2010). Major peat area in Selangor confined mainly to the northern and southern part of Selangor compromising Hutan Melintang and Kuala Langat. Peat as deep as 13 feet has been observed in Kuala Langat area (Wong, 1970).

Selangor have about 17,000 of registered independent oil palm smallholders with about 37,000 hectare of oil palm area. In Selangor about $4 \%$ or 32,109 hectare and $17.8 \%$ or 33,986 hectare of oil palm were planted on Suitable (S) and Marginal (M) land of oil palm respectively (Azhar et al., 2012).

\section{GIS and GPS Processing}

The list of BSR infected land belongs to smallholders in Selangor were obtained from MPOB and the GPS coordinate of each individual land reported to be infected with BSR were recorded using Trimble ${ }^{\circledR}$ Geographical Positioning System (GPS) device. Total GPS coordinate of BSR incidences collected for this study was 168 . The data of BSR incidence were recorded based on visual inspection by smallholder's extension officer of MPOB. The map were then layered using the MapInfo ${ }^{\circledR}$ software. GPS coordinate were overlain on top of the soil series map of Selangor (Fig. 2). Soil series map of Selangor (Fig. 3) were obtained from Malaysian Palm Oil Board (MPOB). BSR incidences were linked to the soil series based on percentage of coordinate that overlay with the type of soil series. This map directly helps to know if there is any specific relation between the types of soil series and the distribution of BSR incidence.

\section{Results and Discussion}

Based on the results, majority of the BSR incidence were confined to the Selangor-Kangkong soil series which is $49.4 \%$ followed on Peat soil which is $30.96 \%$, Kranji soil of $11.31 \%$ and Briah-Organic Clay and Muck of $8.33 \%$ as shown in Table 3 and its respective graph in Fig. 4. The result were also in consistent with the report by Navaratnam (1964) which reported high incidence of BSR on SelangorKangkong soil series.

Figure 5 shows the distribution map of BSR incidence based on soil series of Selangor. Based on the figure, most of the incidences were confined to the district of Kuala Langat, Sepang and Sabak Bernam which is inline with the highest oil palm cultivation area in Selangor. However, the lack of BSR disease incidence in Kuala Selangor district which were known to have high area of oil palm cultivation are due to lack of reliable data on BSR incidence in this area.

Based on the distribution pattern, most of the incidences are confined along the coastal area which probably due to planting of oil palm in previous coconut stands. However, no further data on history of coconut planting is available to support this assumption. Ganoderma were not reported as a pathogen of coconut palms in Malaysia, but it were reported to act as an inoculums source for the pathogen to infect oil palm (Gurmit 1991; Rolph et al., 2000). Abdullah (2000) reported there were no Ganoderma Boninense sporophores were ever observed on the standing coconut palm. There is not much reports on large infections of Ganoderma on coconut which cause severe damage in Malaysia apart from a report by Navaratnam (1964) which reported dead coconut stumps and logs that support Ganoderma fruiting bodies without mentioning the severity of infection. This may raise questions on the diferences in severity of infection and damage between oil palm and coconut. It can be suggested that the cocount palm can be infected by the Ganoderma but their severity is not as high as oil palm which resulted the tree to fall. However, when planting of oil palm were done on previously planted coconut infected with Ganoderma, it can be a source of inoculum which easily cause severe damage to the oil palm which result in falling of the tree.

In contrast to Ganoderma infection to coconut in Malaysia, these diseases have been reported to cause serious damage to coconut in India (Sankaran et al., 2005). Abdullah (2000) suggesting that the different response of Malaysian coconuts towards Ganoderma probably due to different variety of coconut in Malaysia compare to India. It has been speculated that the disease are not able to cause serious damage to Malaysian coconut of tall variety compare to short variety coconut of India (Abdullah, 2000).

Based on the $\mathrm{pH}$ of soil series as shown in Table 4 and its respective graph in Figure 6, low $\mathrm{pH}$ of Selangor and Peat soil series shows a high BSR incidence while high $\mathrm{pH}$ of Kranji and Briah soil series shows slightly lower BSR incidence. This finding is consistent with report by Nawawi and Ho (1990) which reported that Ganoderma boninense found to grow at an optimum $\mathrm{pH}$ between 3.7 to 5 under laboratory condition. 


\section{Percentage of BSR incidence based on soil series}

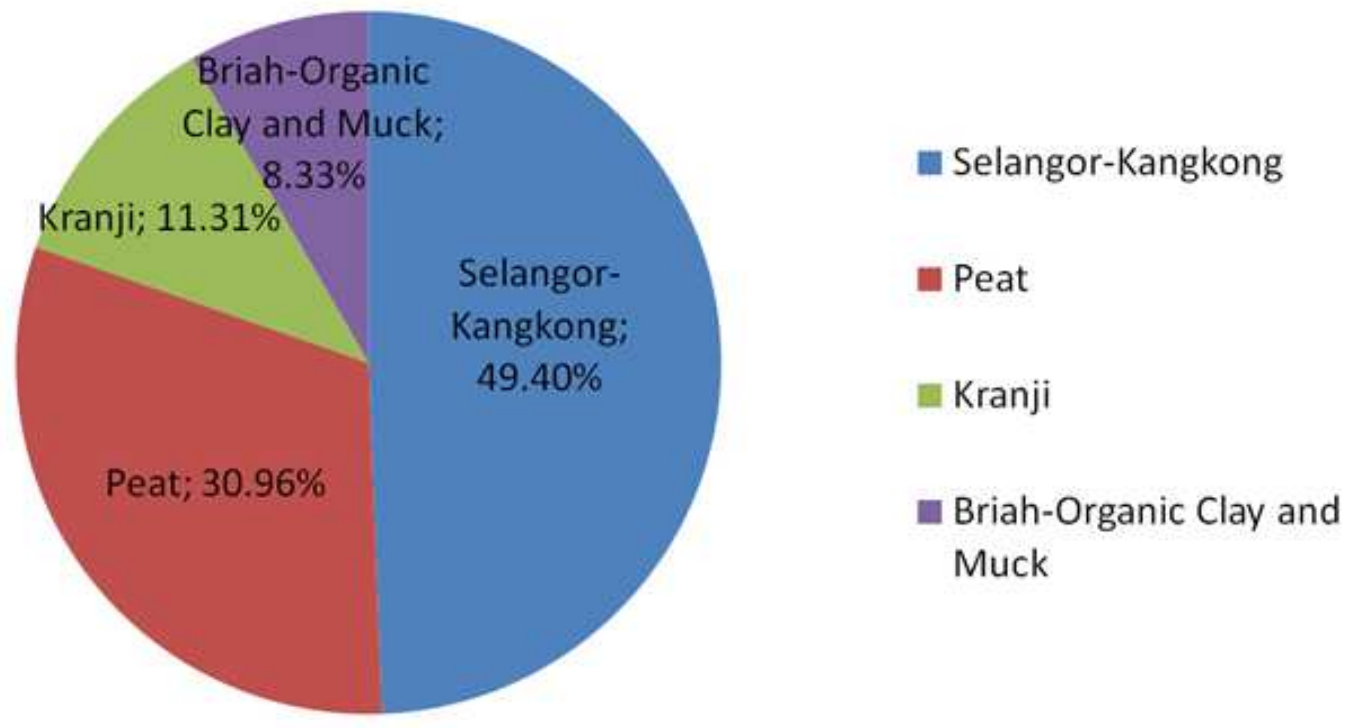

Fig. 4. Graph of percentage of BSR incidence based on soil series

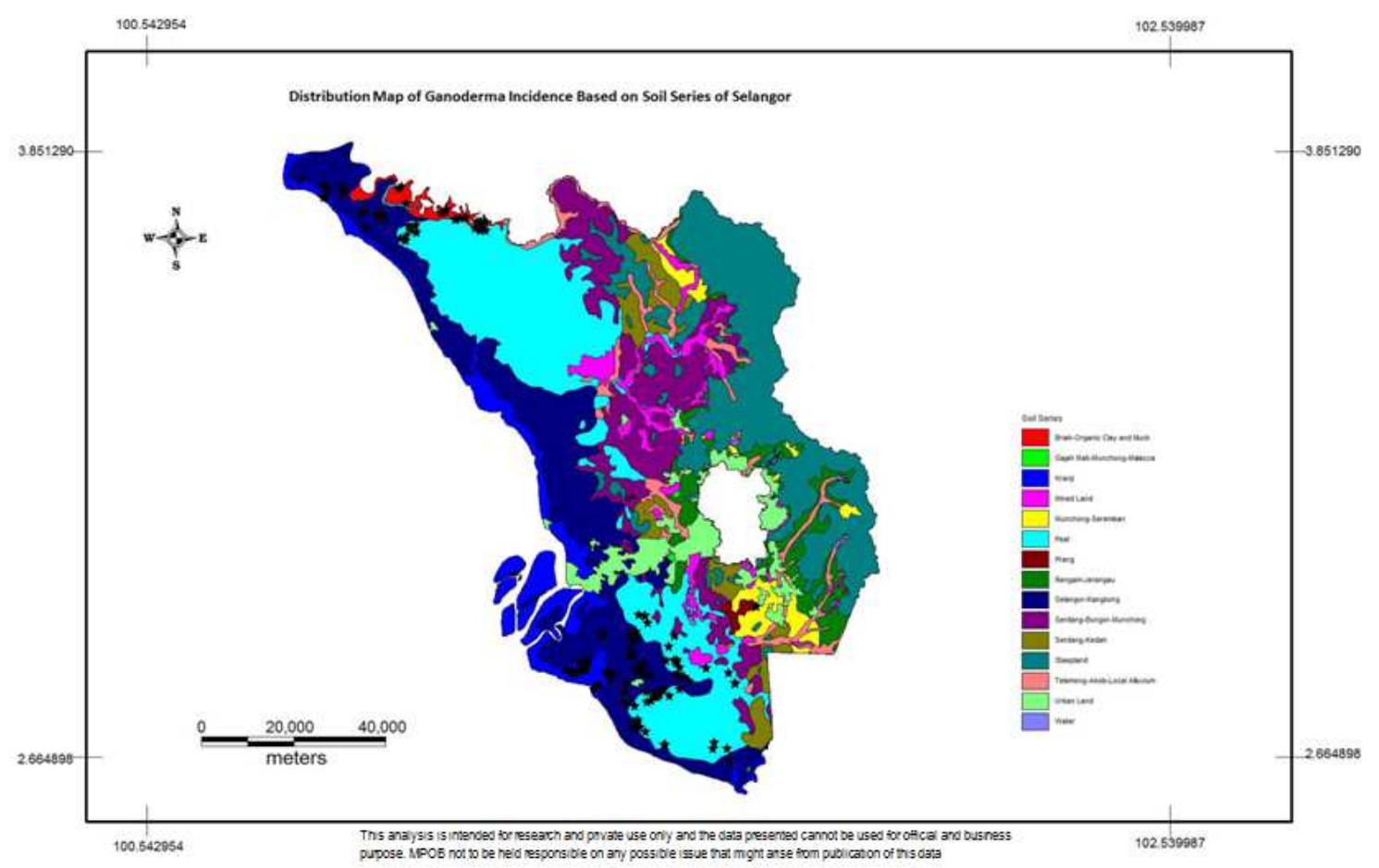

Fig. 5. Distribution map of BSR incidence based on soil series of Selangor

Table 3. Number and percentage of BSR incidence based on soil series

\begin{tabular}{llll}
\hline Soil series (local name) & USDA soil taxanomy & BSR incidence (point) & BSR incidence (\%) \\
\hline Selangor-Kangkong & Aeric Tropic Fluvaquent & 83 & 49.40 \\
Peat & Typic Fibric Tropohemist & 52 & 30.96 \\
Kranji & Typic Sulfaquents & 19 & 11.31 \\
Briah-organic clay and muck & Typic Fluvaquent & 14 & 8.33 \\
\hline
\end{tabular}


Table 4. pH of soil series (Wong, 1970) and BSR incidence

\begin{tabular}{lllc}
\hline Soil series (local name) & USDA soil taxanomy & $\mathrm{pH}$ & BSR incidence (\%) \\
\hline Selangor & Aeric Tropic Fluvaquent & $3.4-3.9$ & 49.40 \\
Peat & Typic Fibric Tropohemist & $3.2-4.5$ & 30.96 \\
Kranji & Typic Sulfaquents & $6.0-7.5$ & 11.31 \\
Briah-organic clay and muck & Typic Fluvaquent & $3.9-4.3$ & 8.33 \\
\hline
\end{tabular}

Graph of pH of soil series (Wong, 1970) and BSR incidence

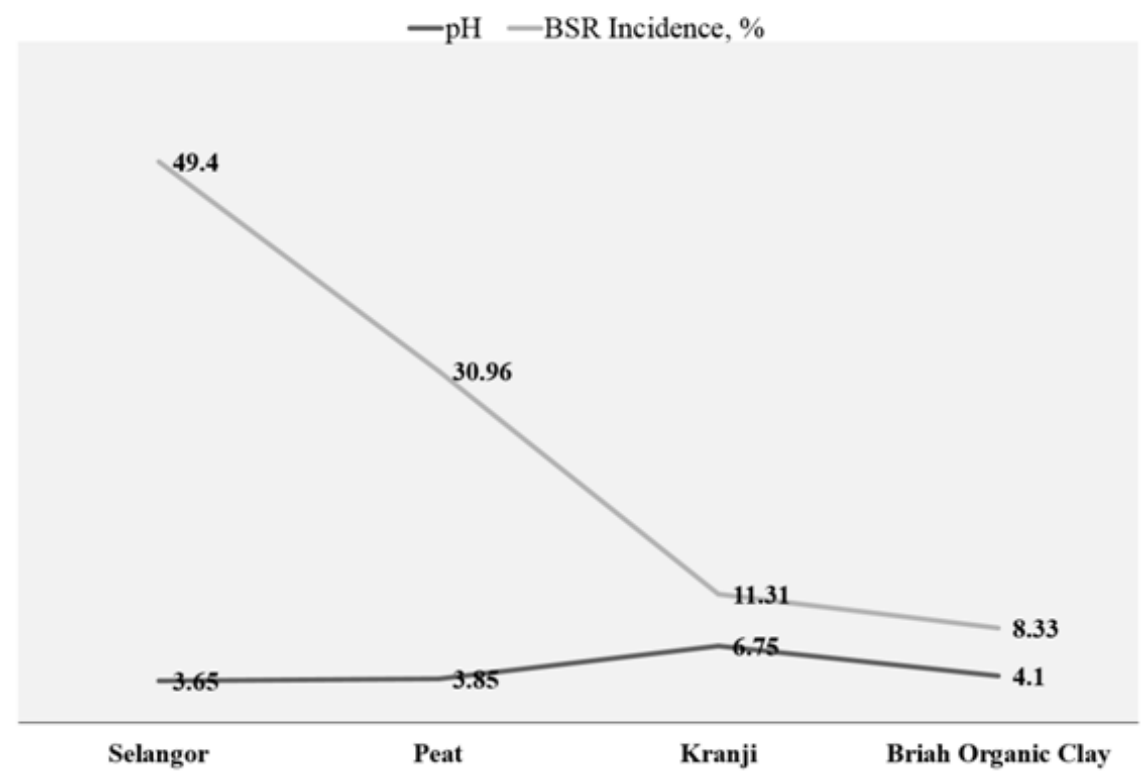

Fig. 6. Graph of pH of soil series (Wong, 1970) and BSR incidence

However, this findings is contradict with report from Gurmit (1991) who noted that low $\mathrm{pH}$ appeared to discourage BSR incidence under field study based on lower incidence found on acid sulphate (Sedu series) and on recent marine soils (Table 1). Fungi known to dominate all types of soils and represent the greatest diversity among soil microorganisms. The quality and quantity of organic matter as well as other soil properties have a direct influence on fungal distribution in soils. Fungi are dominant in acids soils because acidic environment is not conducive for existence of either bacteria or actinomycetes, resulting in the monopoly of fungi for utilization of native substrates in soil (Giri et al., 2005).

The Selangor, Kangkong, Kranji and Briah soils are considered from marine alluvium soils. Approximately one-third of the total area of Selangor is under the marine alluvium soils which forms the western coastal plain of Selangor. This soil category under natural undrained condition is in greenish grey or bluish grey in colour and when drained the surface of the soil changes to a grey colour with distinct mottles of yellow and red indicating the oxidation of sulphur and iron compounds occurring within the soil. These categories of soils are one of the most fertile soils in the country. It contains more than $50 \%$ montmorillonite clay and is known to contain a high proportion of phosphorus in the organic topsoil. Potassium and magnesium reserves are also high (Wong, 1970). The fact that these soils are mainly clays, clay loams or silty clays with a high water retention capacity and poor internal drainage may have favour the BSR incidence although the effect of soil moisture on BSR incidence has been subject to contradiction by different reports. The peat soils on the other hand which known to have high organic matter content are able to hold water which contribute to high water retention also can favour the BSR incidence.

Selangor series is one of the most extensive soils on the coastal plain of Selangor. It also considered as one of the most fertile soils in Malaysia with high reserves of nutrients and clay minerals dominated with montmorillonite and were considered class I for oil palm besides coconut, bananas, pineapples, coffee and fruit trees (Pushparajah and Selvadurai, 1999). When imperfectly drained it would be in class II soil while under irrigated condition it changed to class III which is suitable for paddy cultivation. Selangor series have clay parent material at a depth of less than $60 \mathrm{~cm}$ due to high water table under natural condition. Improved drainage system will improve the soil. The top soil is dark brown silty clay loam while the subsoil is dark greyish brown to greyish brown which consist of silty clay to a depth of 
three or four feet. Rubber has been grown successfully without fertilizer application in this soil series due to the marine clay parent material which is rich in plant nutrients. However, continuous cropping will deplete the nutrient reserve which requires fertilizer application.

Kangkong series also considered one of the most fertile soils in Malaysia. It is formed on the more recent marine clay deposits and mostly found to be confined to the northwestern region of the state near the mouth of Sungai Bernam (Wong, 1970). This soil is usually in class II soil as it is imperfectly drained while when well drained it is a class I soil. It is suitable for rubber, coconuts and oil palm as well for paddy when irrigated. It is characterized by grey, light grey or greenish grey clay subsoil. The parent material is massive bluish grey clay.

Briah soil series is commonly formed on a mixture of recent riverine and recent marine alluvium, especially when the soils are located along the levees of the rivers passing through the marine coastal plain. The top soil is characterized by dark brown silty clay while the subsoil is light brown or brownish grey silty clay loam. The parent material is brownish grey silty clay. These soils are imperfectly to poorly drained and have a low permeability. Briah soil under natural condition is in class III and when well drained it will be in class I while under imperfectly drained will be in class II. With adequate drainage, this soil will support a very good stand of oil palm. The high exchangeable magnesium in these soils can cause precoagulation of latex and thereby limit latex production of rubber cultivation (Paramananthan, 2000).

Kranji soil series consists of a thin topsoil of dark greyish brown organic clay. These soils are normally under tidal influence and very saline soils which need drainage to support coconut and paddy. It was developed on marine clays under swamp conditions. It is found in the mangrove swamp areas over recent marine and estuarine clays on the mainland coast and on the islands off the coast. This soil in natural state is in high saline condition and a tendency to increase in acidity as a result of oxidation of sulphur compounds to sulphate following drainage and aeration. It is in class IV soils due to very poor drainage and saline condition.

Peat normally formed on the former lagoons behind the fore beach. The underlying material is normally clay on the west coast while sandy clay on the east coast. Normally peat of more than $150 \mathrm{~cm}$ depth poses problems to agriculture such as deficiency in micronutrients and acidity.

Apart from the type of soil, other factors such as nutrient content, palm age, temperature, $\mathrm{pH}$ and planting technique can influence the development of BSR. As for example, the intensity of BSR infection would depends on the rate of initial colonization based on the concentration of the fungus. Ganoderma species although present in natural stands in the forest, their disease incidence is low compare to monocropping in a plantation. It can be suggested that there are some factors that keep the disease under control in a forest environment such as biological related factors although it can be argued that the increase probably as a result of large scale monocropping in plantation. Cooper et al. (2011) reported that Ganoderma are relatively a weak pathogen which requires large inoculum to initiate an attack and it also a weak competitor against other saprotrophic microflora. Apart from that, proximity and time of the colonized tissue or inoculums to make contact with the oil palm also can be one of the factors. Type of previous crop planted prior to oil palm may have effect on the intensity of infection but research need to be done if there is there any significant relationship between type of previous crop and BSR incidence occurrence.

The spread of BSR is thought to be mainly by root to root contact between palm and sources of infection (Gurmit, 1991; Rees et al., 2009). This is in line with the roots of mature oil palm tree which can spread up to four planting rows resulted in frequent root contacts (Miller et al., 1999). However, the root to root spreading were not fully accepted as the only mode of spreading of the disease as there are also possibility that it would be spread by basidiospores which were produced and released by fruiting bodies or sporophore (Miller et al., 1999; Sanderson et al., 2000; Sanderson, 2005). However, the spread by spore might not be the major cause of BSR infection in the field. It is because the incidence of BSR in the field should be very high if the spread by spore were the major cause of BSR infection. Therefore, a better understanding of the inoculums source and mode of spreading are important Ganoderma research.

\section{Conclusion}

The distribution of BSR were mostly confined to the coastal areas which were believed to be due to the planting of oil palm in previous coconut stands rather than any relationship with the type of soil series. There are still many area of uncertainty regarding the BSR infection such as the information on establishment of the causal fungus, their mode of action in oil palm as well as the environmental factors that are influencing the spread BSR disease. Increasing reports of BSR disease in different soil types indicating that this disease has become a serious threat to the oil palm industry. Over the years, a number of factors have been reported to influence the development of BSR disease such as type of soils, nutrient content, palm age, temperature, $\mathrm{pH}$ and planting technique. However, it is not clear which of this factors poses a major effect on BSR development. Therefore, further research is necessary to clarify any major factor that has relationship with BSR incidence. For the future efforts, information on GPS position of 
BSR incidence can be integrated with other information such as $\mathrm{pH}$, rainfall, nutrient content and temperature map which will help in determining if there is any specific relationship between BSR incidences with these parameters. Further research also needs to focus on the biological factors that are different between these two ecosystems such as the present of specific fungus or bacteria in soil which might contribute in the biological management of Ganoderma.

\section{Acknowledgment}

The authors are grateful to the Malaysian Palm Oil Board (MPOB) for their support in conducting this research.

\section{Funding Information}

This work was supported by the Malaysian Palm Oil Board. The authors would like to express their sincere appreciation for the support provided.

\section{Author's Contributions}

All authors read and approved the final manuscript.

K. Parthiban: Carried out the data collecting, analysis and writing of the manuscript.

A.A. Nordiana: Participated in the analysis of data. R. Vanitah, K. Jusoff, A.R. Anuar, O. Wahid and A.B. Hamdan: Helped in coordination and drafting of the manuscript.

\section{Ethics}

The authors declare no competing interests.

\section{References}

Abdullah, F., 2000. Spatial and sequential mapping of the incidence of basal stem rot of oil palms (Elaeis guineensis) on a Former Coconut (Cocos nucifera) Plantation. In: Ganoderma Diseases of Perennial Crops. Flood, J., P.D. Bridge and M. Holderness (Eds.), CABI Publishing, UK, ISBN-10: 0851999468, pp: 183-194.

Alabouvette, C., 1999. Fusarium wilt suppressive soils: An example of disease-suppressive soils. Australasian Plant Pathol., 28: 57-64. DOI: 10.1071/AP99008.

Arif, M.A., A. Roslan, A.S. Idris and M. Ramle, 2011. Economics of oil palm pests and Ganoderma diseases and yield losses. Proceedings of the 3rd International Seminar: Integrated Oil Palm Pests and Diseases Management (PDM' 11) Malaysia: MPOB, pp: 83-98.
Azahar, T.M., J.C. Mustapha, S. Mazliham and P. Boursier, 2011. Temporal analysis of basal stem rot disease in oil palm plantations: An analysis on peat soil. Int. J. Eng. Technol., 11: 96-101.

Azhar, I., S. Norasmawati, Z. Zuhaili, R. Murni and H. Norfarezah et al., 2012. Determination of oil palm suitability using GIS at district levels in peninsular Malaysia. Malaysian Meteorological Department, Ministry of Science, Technology and Innovation, Malaysia.

Chang, T.T., 2003. Effect of soil moisture content on the survival of Ganoderma species and other woodinhabiting fungi. Plant Dis., 87: 1201-1204. DOI: 10.1094/PDIS.2003.87.10.1201

Cooper, R.M., J Flood and R.W. Rees, 2011. Ganoderma boninense in oil palm plantations: Current thinking on epidemiology, resistance and pathology. Planter, 87: 515-526.

Economic Planning Unit of Selangor, 2014. Peta Daerah Negeri Selangor.

Giri, B., P.H. Giang, R. Kumari, R. Prasad and A. Varma, 2005. Microbial Diversity in Soils. In: Microorganisms in Soils: Roles in Genesis and Functions, Buscot, F. and A. Varma (Eds.), Springer Berlin Heidelberg, ISBN-10: 978-3-540-26609-9, pp: 19-55.

Gurmit, S., 1991. Ganoderma - the scourge of oil palm in the coastal area. Planters, 67: 421-444.

Idris, A.S., D. Ariffin, T.R. Swinburne and T.A. Watt, 2000a. The identity of Ganoderma species responsible for Basal Stem Rot (BSR) disease of oil palm in Malaysia-morphological characteristics.

Idris, A.S, D. Ariffin, T.R. Swinburne and T.A. Watt, 2000b. The identity of Ganoderma species responsible for Basal Stem Rot (BSR) disease of oil palm in Malaysia-pathogenicity test.

Khairudin, H., 1990. Results of four trials on Ganoderma basal stem rot of oil palm in Golden Hope estates. Proceedings of the Ganoderma Workshop, Sep. 11-11, Malaysia, pp: 67-80.

Miller, R.N.G., M. Holderness, P.D. Bridge, G.F. Chung and M.H. Zakaria, 1999. Genetic diversity of Ganoderma in oil palm plantings. Plant Pathol., 48: 595-603. DOI: 10.1046/j.1365-3059.1999.00390.x

MPOB, 2013. Oil palm planted area by States as at December 2013 (Hectares). Economics and Industry Development Division.

Navaratnam, S.J., 1964. Basal stem rot of oil palms on ex-coconuts estates. Planters, 40: 256-259.

Nawawi, A. and Y.W. HO, 1990. Effect of temperature and $\mathrm{pH}$ on growth pattern of Ganoderma boninense from oil palm in Peninsular Malaysia. Pertanika, 13: 303-307.

Olaniyi, A.O., A.M. Abdullah, M.F. Ramli and A.M. Sood, 2012. Factors affecting agricultural land use for vegetables production-a case study of the state of Selangor, Malaysia. Afr. J. Agric. Res., 7: 5939-5948. DOI: 10.5897/AJAR11.1726 
Omar, A.R., H.L. Fook, F.I. Nor, A.S. Idris and K.A.P. Ghulam, 2014. Isolation of partial cDNA clone coding for Ganoderma boninense pde. J. Oil Palm Res., 26: 265-269.

Paramananthan, S., 2000. Soils of Malaysia: Their Characteristics and Identification. 1st Edn., Academy of Sciences Malaysia, Kuala Lumpur, ISBN-10: 9839445065, pp: 616.

Paterson, R.R.M., M. Sariah and N. Lima, 2009. The feasibility of producing oil palm with altered lignin content to control ganoderma disease. J. Phytopathol., 157: 649-656.

DOI: $10.1111 /$ j.1439-0434.2009.01553.x

Paterson, R.R.M., M. Sariah, M.A.Z. Abidin and N. Lima, 2008. Prospects for inhibition of lignin degrading enzymes to control Ganoderma white rot of oil palm. Current Enzyme Inhibit., 4: 172-179. DOI: $10.2174 / 157340808786733613$

Ploetz, R.C., 2000. Panama disease: A classic and destructive disease of banana. Plant Health Progress. DOI: 10.1094/PHP-2000-1204-01-HM

Pushparajah, E. and Selvadurai, 1999. Notes on Agricultural Science II Soils: Field Examination, Identification, Classification (Soil Taxonomy, Soil and Land Suitability) and Mapping-Technical Education Scheme. ISP, Kuala Lumpur, pp: 52.

Rahamah, B.M., S.N. Farhana, A. Khairulmazmi, A. Idris and O. Ahmed et al., 2012. In vitro effects of salicylic acid, calcium and copper ions on growth and sporulation of Ganoderma boninense. Afr. J. Biotechnol., 11: 13477-13489. DOI: $10.5897 / \mathrm{AJB} 12.1968$

Rao, V., C.C. Lim, C.C. Chia and K.W. Teo, 2003. Studies on Ganoderma spread and control. Planter, 79: 367-383.

Rees, R.W., J. Flood, Y. Hasan, U. Potter and R.M. Cooper, 2009. Basal stem rot of oil palm (Elaeis guineensis); Mode of root infection and lower stem invasion by Ganoderma boninense. Plant Pathol., 58: 982-989. DOI: $10.1111 / \mathrm{j} .1365-3059.2009 .02100 . x$

Rolph, H., R. Wijesejara, R. Lardner, F. Abdullah and P.M. Kirk et al., 2000. Molecular Variation in Ganoderma Isolates from Oil Palm, Coconut and Betelnut. In: Ganoderma Diseases of Perennial Crops, Flood, J., P.D. Bridge and M. Holderness (Eds.), CABI Pub., UK, ISBN-10: 0851999468, pp: 205-221.
Roslan, A. and A.S. Idris, 2012. Economic impact of Ganoderma incidence on Malaysian oil palm plantation-a case study in Johor. Oil Palm Industry Economic J., 12: 24-30.

Sanderson, F.R., 2005. An insight into spore dispersal of Ganoderma boninense on oil palm. Mycopathologia, 159: 139-141. DOI: 10.1007/s11046-004-4436-2

Sanderson, F.R., C.A. Pilotti and P.D. Bridge, 2000. Basidiospores: Their Influence on our Thinking Regarding a Control Strategy for Basal Stem Rot of Oil Palm. In: Ganoderma Diseases of Perennial Crops, Flood, J., P.D. Bridge, M. Holderness (Eds.), CABI Publishing, UK, ISBN-10: 0851999468, pp:113-119.

Sankaran, K.V., P.D. Bridge and C. Gokulapalan, 2005. Ganoderma diseases of perennial crops in India-an overview. Mycopathologia, 159, 143-152. DOI: $10.1007 / \mathrm{s} 1$ 1046-004-4437-1

Sariah, M. and H. Zakaria, 2000. The Use of Soil Amendments for the Control of Basal Stem Rot of Oil Palm Seedlings. In: Ganoderma Diseases of Perennial Crops, Flood, J., P.D. Bridge, M. Holderness (Eds.), CABI Publishing, UK, ISBN-10: 0851999468, pp: 89-99.

Shamala, S., 2013. First report: Isolation of Endophytic trichoderma from oil palm (Elaeis guineensis Jacq.) and their in vitro antagonistic assessment on Ganoderma boninense. J. Oil Palm Res., 25: 368-372.

Turner, P.D., 1981. Oil Palm Diseases and Disorders. 1st Edn., Oxford University Press, Kuala Lumpur, pp: 280.

Wetlands International, 2010. A Quick Scan of Peatlands in Malaysia. 1st Edn., Wetlands International, Malaysia, pp: 74.

Wong, I.F.T., 1970. Reconnaissance Soil Survey of Selangor. 1st Edn., Ministry of Agriculture and Lands, Malaysia, pp: 53.

Wong, L.C., C.F.J. Bong and A.S. Idris, 2012. Ganoderma species associated with basal stem rot disease of oil palm. Am. J. Applied Sci., 9: 879-885. DOI: 10.3844/ajassp.2012.879.885 